\title{
Pendampingan Pengembangan Baitulmaal pada Koperasi Syariah Manfaat Surabaya
}

\author{
Ali Hamdan \& Saifuddin \\ STAI An Najah Indonesia Mandiri Sidoarjo \\ Email: alihamdan.sby@gmail.com, pandowo_4@yahoo.com
}

\begin{abstract}
The existence of sharia cooperatives (kopsyah) in Indonesia is relatively new. There are two main pillars of sharia cooperative management, namely social functions (baitulmaal) and business functions (baitut tamwil). The problem that arises in kopsyah in Surabaya is that there is an imbalance in the management of profit-oriented business functions that tend to be dominant compared to their social functions. The factors that caused the weakness of the Baitulmmaal function in Surabaya, the first factor was dominated by management factors, the second factor was more influenced by manpower and environment, while the environmental factors were influenced by the variables the existing muzakki in the kopsyah environment and the unavailability of a juridical basis for kopsyah to manage ZIS funds. Mentoring that the author did on Kopsyah Benefits of Surabaya is conducting training and assistance in the collection and utilization of ZIS and endowments of money to the management staff of Baitulmaal.
\end{abstract}

Abstrak: Keberadaan koperasi syariah (kopsyah) di Indonesia relatif masih baru. Terdapat dua pilar utama pengelolaan koperasi syariah yaitu fungsi sosial (baitulmaal) dan fungsi bisnis (baitut tamwil). Masalah yang muncul pada kopsyah di Surabaya adalah adanya ketimpangan pengelolaan fungsi bisnis yang berorientasi laba cenderung dominan dibandingkan dengan fungsi sosialnya. Faktor-faktor yang menyebabkan lemahnya fungsi baitulmaal di Surabaya, faktor pertama didominasi oleh faktor manajemen, faktor kedua lebih banyak dipengaruhi oleh manpower (SDM) dan environment (lingkungan), sedangkan faktor lingkungan dipengaruhi oleh variabel tidak dilakukannya penggalangan dana dari para muzakki yang ada dilingkungan kopsyah serta belum tersedianya landasan yuridis bagi kopsyah untuk mengelola dana ZIS. Pendampingan yang penulis lakukan pada Kopsyah Manfaat Surabaya adalah melakukan training dan pendampingan pemghimpunan dan pendayagunaan ZIS dan wakaf uang terhadap SDM pengelola baitulmaal.

Kata Kunci: mentoring, baitul mal, koperasi syari’ah. 


\section{PENDAHULUAN}

Undang-undang Nomor 25 Tahun 1992 tentang perkoperasian, mengamanatkan bahwa kedudukan koperasi simpan pinjam / koperasi simpan pinjam pembiayaan syariah (disebutkan Koperasi Jasa Keuangan) sangatlah penting dalam menumbuhkan dan mengembangkan potensi ekonomi rakyat serta dalam mewujudkan kehidupan demokrasi ekonomi yang mempunyai ciriciri demokratis, kebersamaan, kekeluargaan, dan keterbukaan. Sementara itu Undang-undang nomor 20 Tahun 2008 tentang usaha mikro kecil dan menengah pasal 7 ayat (1) huruf a menyebutkan bahwa pemerintah dan pemerintah daerah menumbuhkan iklim usaha dengan menetapkan peraturan perundang-undangan dan kebijakan yang salah satunya meliputi aspek pendanaan.

Hal ini diperkuat dengan pasal 8, bahwa aspek pendanaan sebagaimana dimaksud dalam pasal 7 ayat 1 huruf a tersebut diatas dutujukan dengan maksud untuk : a) Memperluas sumber pendanaan dan memfasilitasi usaha mikro, kecil, dan menengah untuk dapat mengakses kredit perbankan dan lembaga keuangan bukan bank; b) Memperbanyak lembaga pembiayaan dan memperluas jaringannya sehingga dapat diakses oleh usaha mikro, kecil dan menengah; c) memberikan kemudahan dalam memperoleh pendanaan dan tidak diskriminatif dalam pelayanan sesuai dengan ketentuan perundang-undangan ; d) membantu para pelaku usaha mikro dan usaha kecil untuk mendapatkan pembiayaan dan jasa/produk keuangan lainnya yang disediakan oleh perbankan dan lembaga keuangan bukan bank.

Berdasarkan Kepmen No. 91/Kep/M.KUKM/IX/2004 Bab I tentang ketentuan umum di sebutkan bahwa definisi koperasi adalah badan usaha yang beranggotakan orang seorang atau badan hukum koperasi dengan melandaskan kegiatannya berdasarkan prinsip koperasi sekaligus sebagai gerakan ekonomi rakyat yang berdasar atas asas kekeluargaan, sedangkan definis koperasi syariah adalah koperasi yang kegiatan usahanya bergerak di bidang pembiayaan, investasi, dan simpanan sesuai pola bagi hasil (syariah). Definisi dari Unit Jasa Keuangan Syariah selanjutnya disebut UJKS, adalah unit koperasi yang bergerak di bidang usaha pembiayaan, investasi dan simpanan dengan pola bagi hasil (syariah) sebagai bagian dari kegiatan koperasi yang bersangkutan.

Pada Bab II dari Kepmen tersebut menyebutkan tentang tujuan pengembangan koperasi syariah adalah sebagai berikut : meningkatkan program pemberdayaan ekonomi, khususnya di kalangan usaha mikro, kecil, menengah dan koperasi melalui sistem syariah; mendorong kehidupan ekonomi syariah dalam kegiatan usaha mikro, kecil, dan menengah khususnya dan 
ekonomi Indonesia pada umumnya; meningkatkan semangat dan peran serta anggota masyarakat dalam kegiatan Koperasi Jasa Keuangan Syariah..

Pemerintah khususnya Kementerian Koperasi dan UKM berusaha mendorong perluasan sumber-sumber permodalan/pembiayaan yang berasal dari masyarakat berupa Zakat, Infak, Sedekah (ZIS) melalui Koperasi Jasa Keuangan Syariah (KJKS) sebagai pembiayaan alternatif untuk memberikan pelayanan minimal dalam memenuhi kebutuhan Usaha Mikro Kecil, Anggota, dan calon anggota KJKS. Dipilihnya zakat, infak dan sedekah sebagai instrumen yang solutif dan sustainable dikarenakan zakat, infak dan sedekah sebagai instrumen pembangunan, perekonomian, dan pengentasan kemiskinan umat memiliki lebih banyak keunggulan dibandingkan intrumen fiskal lain yang kini telah ada. Berdasarkan Undang-Undang Republik Indonesia Nomor 38 tahun 1999 tentang pengelolaan zakat telah menegaskan bahwa pengelolaan zakat bertujuan :a.Meningkatkan pelayanan bagi masyarakat dalam menunaikan zakat, infak dan sedekah sesuai dengan tuntunan agama; b. Meningkatkan fungsi dan peran pranata keagamaan dalam upaya mewujudkan kesejahteraan masyarakat dan keadilan sosial; c.Meningkatkan hasil guna dan daya guna zakat, infak dan sedekah.

Misi mulia yang diemban KJKS dengan fungsi sosial dan bisnis tersebut merupakan refleksi dari bagian sistem perekonomian Islam yang menghendaki keadilan dalam distribusi pendapatan serta kesempatan berusaha bagi semua lapisan masyarakat. Selain berperan sebagai lembaga pembiayaan, KJKS juga membawa misi sebagai lembaga sosial bagi masyarakat yang membutuhkan melalui akad-akad yang diaplikasikan dalam lembaga tersebut baik yang berbasis keadilan maupun kedermawanan.

Peran KJKS juga strategis dalam rangka mengisi ruang yang tidak dimasuki oleh perbankan dalam menyediakan fasilitas pembiayaan kepada usaha-usaha mikro, mengatasi pengangguran dan meningkatkan kesejahteraan masyarakat. Namun peran KJKS yang telah ada pada kenyataannya belum mampu melayani masyarakat khususnya mereka yang berpenghasilan rendah atau kelompok fakir miskin secara optimal. Sementara keberadaan jasa rentenir yang menawarkan pinjaman cepat dengan bunga begitu tinggi kepada masyarakat yang memiliki kebutuhan mendesak, hingga saat ini masih eksis di beberapa wilayah termasuk juga di Kota Surabaya.

Secara konseptual, koperasi syariah memiliki dua fungsi : Baitul Tamwil (Bait $=$ Rumah, at Tamwil = Pengembangan Harta) yaitu melakukan kegiatan pengembangan usaha-usaha produktif dan investasi dalam meningkatkan kualitas ekonomi pengusaha mikro dan kecil terutama dengan mendorong 
kegiatan menabung dan menunjang pembiayaan kegiatan ekonominya. Baitulmaal (Bait = Rumah, Maal = Harta) yaitu menerima titipan dana zakat, infak dan sedekah serta mengoptimalkan distribusinya sesuai dengan peraturan dan amanahnya. koperasi syariah adalah lembaga keuangan mikro yang memadukan kegiatan ekonomi berupa simpanan dan pembiayaan dalam berbagai jenis akad, serta kegiatan sosial melalui penggalangan titipan dana sosial untuk kepentingan masyarakat serta mendistribusikannya dengan prinsip pemberdayaan masyarakat sesuai aturan dan amanahnya.

Visi koperasi syariah mengarah pada upaya untuk mewujudkan koperasi syariah menjadi lembaga yang mampu meningkatkan kualitas ibadah anggota (ibadah dalam arti yang luas), sehingga mampu berperan sebagai wakil pengabdi Allah SWT, memakmurkan kehidupan anggota pada khususnya dan masyarakat pada umumnya.. Titik tekan perumusan Visi koperasi syariah adalah mewujudkan lembaga yang professional dan dapat meningkatkan kualitas ibadah. Misi koperasi syariah adalah membangun dan mengembangkan tatanan perekonomian dan struktur masyarakat madani yang adil berkemakmuran, serta berkeadilan berlandaskan syari'ah dan diridhoi Allah SWT. Dari pengertian tersebut dapat dipahami bahwa misi koperasi syariah bukan semata-mata mencari keuntungan dan penumpukan laba modal pada golongan orang kaya saja, tetapi lebih berorientasi pada pendistribusian laba yang merata dan adil, sesuai dengan prinsip-prinsip ekonomi Islam.

Istilah baitulmaal sendiri belakangan ini juga populer seiring dengan bangkitnya semangat umat untuk berekonomi secara Islam. Istilah itu biasanya dipakai oleh sebuah lembaga khusus (dalam perusahaan atau instansi) yang bertugas menghimpun dan menyalurkan ZIS (zakat, infaq, sedekah) dari para pegawai atau karyawannya. Kadang dipakai pula untuk sebuah lembaga ekonomi berbentuk koperasi serba usaha yang bergerak di berbagai lini kegiatan ekonomi umat, yakni dalam kegiatan sosial, keuangan (simpan-pinjam), dan usaha pada sektor riil. Memang, niat dan semangat yang tinggi untuk berekonomi Islam itu patut dihargai. Akan tetapi, penggunaan istilah baitulmaal tersebut nampaknya perlu dipertimbangkan lagi secara bijaksana. Karena, penggunaan istilah baitulmaal sekarang ini sebenarnya adalah suatu reduksi, kalau tak dapat dikatakan distorsi terhadap ketentuan syariah Islam tentang baitulmaal. Dalam konsep aslinya seperti yang tersebut dalam ketentuan nash-nash syariat maupun praktek konkretnya dalam sejarah Islam, baitulmaal merupakan salah satu lembaga dalam negara Islam yang tugas utamanya adalah mengelola segala pemasukan dan pengeluaran negara. Baitulmaal merupakan lembaga keuangan negara yang bertugas menerima, menyimpan, dan mendistribuslkan uang negara 
sesuai ketentuan syariat. Baitulmaal dapat disamakan dengan kas negara yang ada dewasa ini.

Jadi, ada yang $\square$ tersamar dengan penggunaan istilah baitulmaal, juga istilah Baitulmaal wat Tamwil, seperti yang terjadi sekarang. Pertama, istilah baitulmaal hanya akan dipahami secara dangkal dan parsial, tidak lagi dipahami sebagai institusi yang terintegrasi dalam negara Islam. Jika disebut baitulmaal, umat tak lagi berpikir lagi tentang Khilafah, yang menjadi payung atau induk keberadaannya, namun yang terpikir adalah aktivitas-aktivitas ekonomi parsial yang dilakukan rakyat, bukan negara. Kedua, penggunaan istilah baitulmaal akan dapat membius atau meninabobokkan umat dan membuat mereka puas dengan apa yang telah mereka capai, sehingga lupa terhadap sistem ekonomi Islam yang hakiki, yang hanya akan terwujud dalam naungan negara. Mereka mungkin akan menyangka, baitulmaal yang ada sekarang adalah kurang lebih sama dengan baitulmaal yang ada dalam sejarah Islam.

Mungkin karena alasan semacam itulah, istilah baitulmaal di Aceh kemudian disepakati untuk diubah namanya menjadi Baitul Qiradh. Di Kuwait sebuah lembaga keuangan diberi nama Baitut Tamwil Al Kuwaiti. Fenomena semacam ini kiranya dapat menjadi bahan pertimbangan dan renungan. Namun, terlepas dari dua istilah itu, konsep baitulmaal itu sendiri memang harus dikaji kembali dengan seksama sesuai dengan ketetuan hukum syariat dan realitas objektif yang terbentang sepanjang sejarah Islam. Dengan demikian, kita akan memiliki persepsi yang benar dan utuh mengenai baitulmaal, termasuk kedudukannya sebagai bagian integral dari Khilafah. Dengan bekal persepsi yang benar inilah, mudah-mudahan kita akan mampu menerapkan konsep baitulmaal secara sempurna dalam realitas kehidupan. Baitulmaal berasal dari bahasa Arab bait yang berarti rumah, dan al-mal yang berarti harta. Jadi secara etimologis (lughawi) baitulmaal berarti rumah untuk mengumpulkan atau menyimpan harta. Adapun secara terminologis (ishtilahi), sebagaimana uraian Abdul Qadim Zallum dalam kitabnya Al Amwaal Fi Daulah Al Khilafah, baitulmaal adalah suatu lembaga atau pihak yang mempunyai tugas khusus menangani segala harta umat baik berupa pendapatan maupun pengeluaran negara. Jadi setiap harta baik berupa tanah, bangunan, barang tambang, uang, komoditas perdagangan, maupun harta benda lainnya di mana kaum muslimin berhak memilikinya sesuai hukum syara' dan tidak ditentukan individu pemiliknya, walaupun telah tertentu pihak yang berhak menerimanya, maka harta tersebut menjadi hak baitulmaal, yakni sudah dianggap sebagai pemasukan bagi baitulmaal. Secara hukum, hartaharta itu adalah hak baitulmaal, baik yang sudah benar-benar masuk ke dalam tempat penyimpanan baitulmaal maupun yang belum. Demikian pula setiap 
harta yang wajib dikeluarkan untuk orang orang yang berhak menerimanya, atau untuk merealisasikan kepentingan kaum muslimin, atau untuk biaya penyebarluasan dakwah, adalah harta yang dicatat sebagai pengeluaran baitulmaal, baik telah dikeluarkan secara nyata maupun yang masih berada dalam tempat penyimpanan baitulmaal. Dengan demikian, baitulmaal dengan makna seperti ini mempunyai pengertian sebagai sebuah lembaga atau pihak yang menangani harta negara, baik pendapatan maupun pengeluaran. Namun demikian, baitulmaal dapat juga diartikan secara fisik sebagai tempat (al-makan) untuk menyimpan dan mengelola segala macam harta yang menjadi pendapatan negara .

\section{PENDAMPINGAN KOPERASI SYARIAH MANFAAT SURABAYA}

Lahirnya koperasi di Indonesia dilatarbelakangi oleh permasalahan yang sama yaitu menentang individualisme dan kapitalisme secara fundamental. Pada Tahun 1908 Budi Utomo menganjurkan berdirinya koperasi untuk keperluan rumah tangga, kemudian untuk menggiatkan pertumbuhan koperasi pada akhir tahun 1930 didirikan jawatan koperasi yang tugasnya menerangkan serta menjelaskan seluk beluk mengenai perkoperasian. Jumlah Koperasi pada tahun 1939 mencapai 1712 buah, dengan jumlah yang terdaftar sebanyak 172 buah dan jumlah anggotanya mencapai 14.134 orang. Tonggak sejarah koperasi berikutnya adalah kongres koperasi pertama yang dilaksanakan pada tanggal 12 Juli 1947 di Tasikmalaya, dimana pada kongres terebut terbentuklah Sentra Organisasi Koperasi Rayat Indonesia (SOKRI). Momen ini juga membuat tanggal 12 Juli sebagai Hari Koperasi Nasional.

Sedangkan untuk koperasi syariah tidak diketahui secara pasti, kapan mulai berkembang di Indonesia, namun secara historis model koperasi yang berbasis nilai Islam di Indonesia telah diprakarsai oleh paguyuban dagang yang dikenal dengan SDI (Sarikat Dagang Islam) oleh Haji Samanhudi di Solo Jawa Tengah yang menghimpun para anggotanya dari pedagang batik yang beragama Islam. Aktivitas SDI sejak berdiri tahun 1905 sampai 1912 berorientasi pada kerjasama ekonomi antar pedagang muslim sebelum berorientasi pada gerakan politik. Keberadaan Sarikat Dagang Islam tidak bertahan lama, karena pada perkembangan selanjutnya Sarikat Dagang Islam berubah menjadi Sarikat Islam yang haluan pergerakannya cendrung bernuansa politik.

Tahun 1918 kalangan pesantren yang dimotori KH Hasyim Asy'ari mendirikan Nabdlatul Tujjar (Kebangkitan Pedagang) dengan kegiatannya yang 
berbentuk koperasi. Kemunculan organisasi ini sebagai respons atas mulai munculnya ide komunisme. Setelah SDI (Sarikat Dagang Islam) mengkonsentrasikan perjuangannya di bidang politik dan Nahdlatul Tujjar bertransformasi menjadi Nahdlatul Ulama tahun 1926 yang berkonsentrasi dakwah gaung koperasi syariah tidak terdengar lagi di Indonesia.

Sekitar tahun 1990 barulah koperasi syariah mulai muncul lagi di Indonesia. Koperasi syariah mulai diperbincangkan banyak orang ketika menyikapi semaraknya pertumbuhan Baitulmaal wat Tamwil di Indonesia. Baitulmaal wat Tamwil yang dikenal dengan sebutan BMT dimotori pertama kalinya oleh BMT Bina Insan Kamil tahun 1992 di Jakarta. Kendati awalnya hanya merupakan KSM syariah (kelompok swadaya masyarakat berlandaskan syariah) namun memiliki kinerja layaknya sebuah bank. Lebih tepatnya lagi pasca reformasi semangat ekonomi syariah dan koperasi syariah muncul kembali di negeri ini. Menurut data Kementerian Koperasi dan Usaha Kecil Menengah saat ini ada 3020 koperasi syariah di Indonesia yang bergerak di berbagai macam kelembagaannya. Kelahiran koperasi syariah di Indonesia dilandasi oleh keputusan menteri (Kepmen) Koperasi dan UKM Republik Indonesia Nomor 91/Kep/M.KUKM/IX/2004 tanggal 10 September 2004 Tentang Petunjuk Pelaksanaan Kegiatan Usaha Koperasi Jasa Keuangan Syariah. Keputusan Menteri ini memfasilitasi berdirinya koperasi syariah menjadi Koperasi Jasa Keuangan Syariah (KJKS) atau Unit Jasa Keuangan Syariah (UJKS), dengan adanya sistem ini membantu koperasi serba usaha di Indonesia memiliki unit jasa keuangan syariah. Dengan demikian dalam rangka mempercepat pertumbuhan dan perkembangan koperasi syariah di Indonesia, ke depannya mutlak diperlukan adanya Undang-Undang Koperasi Syariah tersendiri yang mampu mengakomodir percepatan dari koperasi syariah itu sendiri .

Dalam kaitan akses terhadap layanan KJKS, masyarakat berpendapatan rendah (kelompok defisit) memiliki kepentingan berbeda dengan para aghniya' (kelompok surplus). Kelompok defisit dalam menggunakan jasa KJKS antara lain untuk kepentingan pembiayaan seperti modal usaha, jual beli, atau berkaitan dengan masalah pemenuhan kebutuhan pokok. Sementara kelompok surplus atau orang yang berharta dapat menggunakan jasa KJKS antara lain sebagai tempat penyimpanan (penitipan) hartanya, atau lembaga penyalur Zakat, Infaq, Sadaqah (ZIS) untuk kemudian didistribusikan kepada yang berhak menerimanya.

Kedua kelompok kepentingan tersebut perlu diakomodasi oleh KJKS, dengan sekaligus memainkan peran secara kaffah sebagai lembaga sosial dan sebagai lembaga bisnis. KJKS sebagai lembaga keuangan mikro diharapkan 
dapat lebih fokus pada kelompok sasaran masyarakat miskin dan usaha mikro. Kedua fungsi KJKS tersebut hendaknya saling menopang, apalagi mengingat potensi zakat yang cukup besar dan dapat dikelola untuk memberdayakan umat yang masih mengalami kesulitan dalam memperoleh sumber penghidupan dan pemenuhan kebutuhan pokok.

Pengelolaan zakat oleh lembaga pengelola zakat, apalagi yang memiliki kekuatan hukum formal, akan memiliki beberapa keunggulan anatara lain: pertama, untuk menjamin kepastian dan disiplin pembayar zakat. Kedua, untuk menjaga perasaan rendah diri para mustahik zakat apabila langsung untuk menerima zakat dari muzakki. Ketiga, Untuk mencapai efisiensi dan efektifitas, serta sasaran yang tepat dalam penggunaan harta zakat menurut skala prioritas yang ada pada suatu tempat. Keempat, untuk memperlihatkan syiar Islam dalam semangat penyelenggaraan pemerintahan yang Islami.

Koperasi Jasa Keuangan Syariah (KJKS) begitu marak belakangan ini seiring dengan upaya umat untuk kembali berekonomi sesuai syariah dan berkontribusi menanggulangi krisis ekonomi yang melanda Indonesia sejak tahun 1997. Namun KJKS ternyata dipahami secara sempit sebagai lembaga ekonomi privat yang mengurusi sebagian aspek ekonomi umat, seperti wadiah atau mudharabah.

Baitulmaal dalam pengertian ini, telah dipraktekkan dalam sejarah Islam sejak masa Rasulullah, diteruskan oleh para khalifah sesudahnya, yaitu masa Abu Bakar, Umar bin Khaththab, Utsman bin Affan, Ali Bin Abi Thalib, dan khalifah-khalifah berikutnya, hingga kehancuran Khilafah di Turki tahun 1924. Gagasan konsep baitulmaal yang ideal perlu disusun dengan merujuk kepada ketentuan-ketentuan syariah, baik dalam hal sumber-sumber pendapatan maupun dalam hal pengelolaannya. Sumber-sumber pendapatan baitulmaal adalah fai', ghanimah/anfal, kharaj, jizyah, pemasukan dari harta milik umum, pemasukan dari harta milik negara, usyur, kbumus dari rikaz, tambang, serta harta zakat.

Sedang pengelolaannya didasarkan pada enam kategori harta, yaitu :

1. Harta zakat,

2. Harta untuk menanggulangi terjadinya kekurangan dan untuk melaksanakan kewajiban jihad,

3. Harta sebagai suatu pengganti/kompensasi (badal/ujrah), seperti gaji pegawai negeri,

4. Harta untuk kemaslahatan secara umum yang merupakan keharusan,

5. Harta untuk kemaslahatan secara umum yang tidak merupakan keharusan, 
6. Harta untuk menangani kondisi darurat, semisal bencana alam.

Data dari Dinas Koperasi dan UMKM Kota Surabaya menyebutkan sejak 2006 sampai dengan 2018 jumlah koperasi syariah di Kota Surabaya kurang dari 30 koperasi, sedangkan jumlah koperasi konvensional lebih dari 1300. Hal ini menunjukkan masih diperlukan adanya sosialisasi, koordinasi, penguatan kelembagaan, pengembangan produk, peningkatan kualitas konsultan KJKS, serta pengembangan pasar KJKS yang terencana dan berkelanjutan.

Semua KJKS di Kota Surabaya sekarang ini hanya fokus pada kegiatan bisnisnya saja (bayt al-tamwil) sedangkan kegiatan maal nya hanya menjadi sampingan. Padahal Sebagaimana diatur dalam Peraturan Menteri Negara Koperasi dan UKM RI Nomor : 35.2/PER/M.KUKM/X/2007 tentang Pedoman Standar Operasional Manajemen Koperasi Jasa Keuangan Syariah dan Unit Jasa Keuangan Syariah Bab III halaman 64 juga sudah disebutkan secara rinci tentang kegiatan maal KJKS dan UJKS koperasi.

Penjabaran dari kegiatan maal KJKS dan UJKS koperasi berdasarkan Peraturan Menteri tersebut adalah: 1) KJKS dan UJKS koperasi selain menjalankan kegiatan pembiayaan atau tamwil, dapat menjalankan kegiatan maal dan atau kegiatan pengumpulan dan penyaluran dana Zakat, Infaq dan Sadaqah (ZIS), termasuk wakaf; 2) KJKS dan UJKS koperasi yang menyelenggarakan kegiatan maal harus dikelola dan disupervisi oleh penanggung jawab khusus bidang maal; 3) KJKS dan UJKS koperasi yang menjalankan kegiatan maal wajib memisahkan sistem administrasi dan laporan keuangan kegiatan maalnya dengan kegiatan pembiayaan tamwilnya; 4) Kegiatan bidang maal harus mengacu pada peraturan dan perundang-undangan pengelolaan Zakat, Infaq dan Sadaqah (ZIS); 5) Dalam hal terjadi kesulitan pengelolaan baik karena aspek teknis maupun aspek legal, maka kegiatan maal harus dipisahkan dari kegiatan KJKS dan UJKS koperasi dan dikelola melalui lembaga di luar KJKS dan UJKS koperasi.

Optimalisasi peran KJKS dalam menggerakkan dan meningkatkan kapasitas perekonomian masyarakat khususnya usaha kecil dan mikro perlu mendapat perhatian serta dukungan. Selain itu lembaga ini juga perlu meningkatkan perannya dalam pemberdayaan kelompok fakir miskin yang belum memiliki kapasitas untuk mendapatkan pembiayaan komersil karena tidak memadainya aset yang dimiliki.

Pengelolaan zakat oleh lembaga pengelola zakat, apalagi yang memiliki kekuatan hukum formal, akan memiliki beberapa keunggulan anatara lain : Pertama, untuk menjamin kepastian dan disiplin pembayar zakat. Kedua, untuk menjaga perasaan rendah diri para mustahik zakat apabila langsung untuk 
menerima zakat dari muzakki. Ketiga, Untuk mencapai efisiensi dan efektifitas, serta sasaran yang tepat dalam penggunaan harta zakat menurut skala prioritas yang ada pada suatu tempat. Keempat, untuk memperlihatkan syiar Islam dalam semangat penyelenggaraan pemerintahan yang Islami.

Ide didirikanya Kopsyah Manfaat ini adalah dalam rangka menangkap peluang untuk terus mengembangkan diri serta menjadi bagian motor penggerak perekonomian masyarakat dengan memberikan kontribusi yang riil terhadap pemberdayaan masyarakat terutama kalangan menengah ke bawah dengan sistem syariah. Secara ringkas berikut penulis sampaikan profil dari Koperasi Syariah Manfaat Surabaya yang berkantor di Jl. Gayung Kebonsari No.46 Surabaya , Telp/Fax (031) 72468620. Koperasi Syariah Manfaat Surabaya memiliki No. Badan Hukum : 63/BH/XVI.37/2007 tanggal : 11 April 2007. Visi dari Koperasi syariah Manfaat Surabaya yaitu " memberikan manfaat dan kesejahteraan kepada anggota, usaha mikro, usaha kecil dan stake holder“. Sedangkan misinya adalah Mengembangkan lembaga keuangan islam yang kuat, terpercaya dan memiliki jaringan yang luas; Mengembangkan sumber daya insani yang profesional, cerdas, inovatif dan bertakwa; Memberikan kepercayaan bagi para mitra kerja serta rasa aman bagi semua kalangan yang menikmati jasa lembaga ini dan; Berkomitmen tinggi menjadi lembaga keuangan yang murni sesuai syariah beroreantasi kepada usaha mikro dan kecil.

Produk-Produk Simpanan Koperasi Syariah Manfaat adalah :

1. Simpanan "UMMAT"

Simpanan yang diperuntukkan bagi siapa saja dengan layanan mudah dan fleksible serta bagi hasil yang kompetitif.

2. SI "QUAT" (Simpanan Qurban dan Aqiqah Bermanfaat)

Diperuntukkan bagi mereka yang ingin berkurban di Idul Adha atau mempersiapkan aqiqah bagi anak.

3. SI "WALI" ( Simpanan Walimatul Ursy)

Mempersiapkan hari pernikahan lebih terprogram dan terencana.

4. SI "PINTAR" (Simpanan Pendidikan dan Pelajar)

Simpanan bagi pelajar atau santri untuk mempersiapkan masa depannya.

5. SI "MUDAH” (Simpanan Berjangka Mudharabah )

Adalah produk alternatif investasi yang pengambilannya pada waktu tertentu sesuai dengan kesepakatan dan perjanjian, beberapa keuntungan penyimpanan dana melalui SIMUDAH: Halal, karena dikelola secara syariah; Pelayanan yang fleksibel; Bagi hasil yang kompetitif; Aman, karena dikelola oleh lembaga yang berpengalaman dan SDM yang profesional; Khusus penyimpan komunal, simpanan dapat dijemput; ARO, Automatic Roll Over 
yaitu otomatis diperpanjang apabila nasabah tidak datang ketika jangka waktu investasi berakhir (SIMUDAH).

Produk-produk piutang dan pembiayaan Koperasi Syariah Manfaat meliputi pembiayaan produktif dan konsumtif. Pembiayaan produktif dengan memakai akad mudharabah dan musyarakah. Akad Mudharabah adalah akad kerja sama usaha antara dua pihak, di mana pihak pertama (shahibul maal) menyediakan seluruh modal (100\%), sedangkan pihak lainnya adalah pengusaha/pengelola (mudharib). Keuntungan usaha dibagi menurut kesepakatan yang dituangkan dalam kontrak perjanjian. Apabila terjadi kerugian, maka ditanggung oleh shabibul maal (selama kerugian itu bukan karena kelalaian mudharib). Apabila karena kelalaian mudharib, maka yang bersangkutan yang harus menanggung kerugian tersebut. Adapun Musyarakah adalah akad kerja sama antara dua pihak atau lebih untuk suatu usaha tertentu di mana masing-masing pihak memberikan kontribusi dana atau amal / expertise dengan kesepakatan bahwa keuntungan dan resiko akan ditanggung bersama sesuai dengan kesepakatan.

Sementara Pembiayaan Konsumtif berdasarkan pada akad murabahah dan ijarah. Murabahah (Jual Beli) Adalah akad transaksi jual beli suatu barang di mana penjual menyebutkan harga jual yang terdiri dari harga pokok barang dan tingkat keuntungan (margin) tertentu atas barang, dan harga jual tersebut disetujui oleh pembeli. Karakteristiknya adalah penjual harus memberitahukan harga produk yang dibelinya dan menentukan suatu tingkat keuntungan (margin) sebagai tambahannya. Pembelian barang untuk kepentingan konsumtif seperti : HP, Lemari Es, Mesin Cuci, TV, Lap Top, dll. Adapun Ijarah (Sewa) adalah pemindahan hak guna (manfaat) atas suatu aset dalam waktu tertentu dengan pembayaran sewa (ujroh) tanpa diikuti dengan pemindahan kepemilikan aset itu sendiri, serta kontrak yang melibatkan suatu barang (sebagai harga) dengan jasa atau manfaat atas barang lainnya. Seperti sewa rumah, ruko, kendaraan, dan (khusus pendidikan dan pernikahan akadnya ijarah multi jasa).

Selain pembiayaan produktif ada juga pembiayaan Konsumtif yang meliputi: Murabahah (Jual Beli) yaitu akad transaksi jual beli suatu barang di mana penjual menyebutkan harga jual yang terdiri dari harga pokok barang dan tingkat keuntungan (margin) tertentu atas barang, dan harga jual tersebut disetujui oleh pembeli. Karakteristiknya adalah penjual harus memberitahukan harga produk yang dibelinya dan menentukan suatu tingkat keuntungan (margin) sebagai tambahannya. Pembelian barang untuk kepentingan konsumtif seperti : HP, Lemari Es, Mesin Cuci, TV, Lap Top. Ijarah (Sewa) yaitu pemindahan hak guna (manfaat) atas suatu aset dalam waktu tertentu dengan pembayaran sewa (ujroh) tanpa diikuti dengan pemindahan kepemilikan aset itu sendiri, serta kontrak yang 
melibatkan suatu barang (sebagai harga) dengan jasa atau manfaat atas barang lainnya. Seperti sewa rumah, ruko, kendaraan, dan (khusus pendidikan dan pernikahan akadnya ijarah multi jasa).

Selain produk bisnis berupa piutang dan pembiayaan seperti diatas, koperasi syariah manfaat juga mengembangkan baitulmaal untuk memenhi fungsi sosialnya. Selama rentang Januari sampai Juni 2018 terkumpul sana ZIS dan wakaf uang sejumlah Rp. 38.329750,-. Strategi yang dilakukan oleh penanggung jawab baitulmaal, saudari Yani, adalah dengan menghubungi donatur rutin, sebar flayer melalui sms, whatsapps dan media sosial tentang baitulmaal manfaat, menyebarka proposal ke lembaga / instansi yang potensial dan distribusi kotak / kaleng. Cara penghimpunan yang seperti ini menurut penulis sudah benar akan tetapi kurang memberikan penambahan hasil ZIS dan wakaf uang yang signifikan. Saran yang penulis lakukan adalah penghimpunan melalui finansial technologi (fintech). Memang cara ini membutuhkan sarana berupa aplikasi yang bisa dimanfaatkan oleh anggota serta sosialisasi yang terus menerus kepada anggota.

Beberapa program pendayagunaan yang penulis dampingi untuk mengembangkan baitulmaal manfaat antara lain :

1. Santunan pena yatim dhuafa

Merupakan program santunan pendidikan bagi anak yatim dan dhuafa disekolahnya untuk memotivasi semangat belajar dan prestasi seta bisa meringankan beban biaya sekolah

2. Wisata edukatif anak yatim dan dhuafa

Merupakan program wisata edukasi yang dilaksanakan pada saat liburan sekolah untuk anak yatim dan dhuafa dengan mengajak anak-anak tersebut unuk belajar di alam sambil berwisata. Memberikan kegembiraan dan kesempatan pada anak-anak tersebut untuk dapat merasakan suasana baru dalam belajar sambil bermain dan berwisata.

3. Sedekah sembako awal bulan

Merupakan program sedekah sembako yang dilaksanakan bisa secara rutin disetiap awal bulan, dengan penerima manfaat yang berbeda. Program ini diharapkan dapat membantu pemenuhan sembako pada keluarga dhuafa.

4. Dapur dhuafa

Merupakan program sosial yang bertujuan membantu perekonomian ibu-ibu rumah tangga (mustahik) dengan memberikan peluang memasak makanan untuk dibagikan pada masyarakat sekitar yang mustahik pada setiap hari jumat dengan membagi nasi bungkus. Program ini juga diharapkan bisa menumbuhkan jiwa enterpreneurship yang menjadikan ketrampilan memasak 
menjadi sebuah usaha yang tidak hanya menghasilkan keuntungan tapi juga memberikan manfaat kepada sesama.

5. Wakaf uang dan wakaf berupa uang (pusat peradaban ibu)

Merupakan program penghimpunan wakaf uang dan wakaf melalui uang yang dikelola secara professional dengan harapan dana yang terkumpul dapat digunakan untuk membangun gedung wakaf pusat peradaban ibu.

6. Bingkisan kebaikan

Merupakan program pemberian bingkisan kepada para dhuafa dengan membelikan barang yang dibutuhkan dan sifat program ini hanya insidentil.

Dengan banyaknya pilihan program yang ditawarkan kepada anggota harapannya jumlah penghimpunan dana ZIS dan wakaf uang dapat ditingkatkan. Harapan lain dengan banyaknya variasi program baitulmaal bisa menarik partisipasi aktif dari para anggota untuk ikut berperan serta dalam program kebaikan tersebut.

Selain produk bisnis berupa piutang dan pembiayaan seperti diatas, koperasi syariah manfaat juga mengembangkan baitulmaal untuk memenuhi fungsi sosialnya. Sumber dana zakat, infaq, dan sedekah pada koperasi syariah Manfaat dibagi menjadi 2 yaitu: Sumber dari dalam KJKS, sumber dana dari dalam Kopsyah Manfaat maksundnya adalah zakat, infaq, shadaqoh yang di dapat dari semua anggota Kopsyah Manfaat baik itu staf maupun pemilik modal, yang diambil dari gaji, bonus, bagi hasil dari semua tabungan maupun pembiayaan nasabah yang ada. Sedangkan Sumber dari luar Kopsyah Manfaat adalah sumber yang di dapat dari masyarakat luar Kopsyah Manfaat yang ingin mempercayakan dananya untuk di kelola oleh Kopsyah Manfaat.

Selama rentang Januari sampai Juni 2018 terkumpul sana ZIS dan wakaf uang sejumlah Rp. 38.329750,-. Strategi yang dilakukan oleh penanggung jawab baitulmaal, saudari Yani, adalah dengan menghubungi donatur rutin, sebar flayer melalui sms, whatsapps dan media sosial tentang baitulmaal manfaat, menyebarkan proposal ke lembaga / instansi yang potensial dan distribusi kotak / kaleng. Cara lain yang dilakukan koperasi adalah melakukan kerjasama sinergi penghimpunan dengan lembaga yang lain (baik koperasi syariah maupun lembaga amil zakat) untuk sebuah proyek yang telah disepakati bersama. Cara penghimpunan yang seperti ini menurut penulis sudah benar akan tetapi kurang memberikan penambahan hasil zakat, infak maupun sedekah maupun wakaf uang yang signifikan. Saran yang penulis lakukan adalah penghimpunan melalui finansial technologi (fintech). Memang cara ini membutuhkan sarana berupa aplikasi yang bisa dimanfaatkan oleh anggota serta sosialisasi yang terus menerus kepada anggota. Di tahun 2018 Koperasi Syariah Manfaat mencoba bekerja 
sama dengan PT. Ammana Fintech sebuah perusahaan fintech syariah yang telah melakukan kerjasama dengan Koperasi Sekunder di Jawa Timur, akan tetapi masih terfokus pada produk pembiayaan belum sampai ke produk baitulmaal atau produk sosial yang lainnya.

\section{KESIMPULAN}

Koperasi syariah sebagai lembaga bisnis dan sosial, seharusnya dapat berperan secara seimbang. Selama ini kecenderungan koperasi syariah lebih fokus pada pengembangan bisnisnya (baitut tamwi), sedangkan pengembangan soisalnya hanya bersifat sampingan saja. Pendampingan yang dilakukan pada koperasi syariah berupaya untuk mengembangkan baitulmaal manfaat agar bisa lebih berdaya seperti baitut tamwilnya. Baitulmaal memilki kesamaan fungsi dan peran dengan Lembaga Amil Zakat (LAZ), oleh karena itu, baitulmaal harus didorong agar mampu berperan secara profesional menjadi LAZ yang mapan. Adapun fungsi tersebut paling tidak meliputi upaya pengumpulan dana zakat, infaq, sedekah, wakaf dan sumber dana-dana sosial yang lain, dan upaya pendayagunaan dana ZIS dan wakaf tersebut harus bisa variatif sehingga bisa menarik anggota untuk ikut berperan serta. Diantara program pendayagunaan yang didampingi untuk pengembangan baitulmaal manfaat antara lain : Santunan pena yatim hhuafa, wisata edukatif anak yatim dan dhuafa, sedekah sembako awal bulan, dapur dhuafa, wakaf uang dan wakaf berupa uang (pusat peradaban ibu), bingkisan kebaikan. []

\section{DAFTAR PUSTAKA}

Zallum, Abdul, 1983, Al Amwal Fi Daulah Al Khilafah. Cetakan I. Beirut : Darul Ilmi Lil Malayin

Dahlan, Abdul, 1999, Ensiklopedi Hukum Islam. Cetakan II. Jakarta : PT Ichtiar Baru van Hoeve.

Maskanul, Cecep , 1995, Konsep Pengembangan Baitulmaal. Paper Seminar Ekonomi Islam ICMI Bandung.

Hafiduddin, Didin, 2002 Panduan Zakat bersama Dr. KH Didin Hafidhuddin, Jakarta : Penerbit Republika.

Tanjung, Hendri, 2018, Quo V adis Koperasi Syariah, Jakarta: Peluang.

Mubarok, Jaih, 2017, Fikih Mu'amalah maliyah Akad Jual Beli, Bandung : Simbiosa Rekatama Media.

Kepmen Koperasi dan UKM No. 91/Kep/M.KUKM/IX/2004 
Kementerian Agama RI, 2005, Strategi Pengembangan Wakaf Uang di Indonesia. Jakarta: Direktorat Pengembangan Zakat dan Wakaf.

Permen Koperasi dan UKM No 11/Per/M.KUKM/XII/2017

Qarashawi, Yusuf , 1997,Norma dan Etika Ekonomi Islam. Jakarta : Gema Insani Press. 
